\title{
Correlation between $n-3$ polyunsaturated fatty acids consumption and BDNF peripheral levels in adolescents
}

Charles Francisco Ferreira 1,2,36*, Juliana Rombaldi Bernardi ${ }^{3}$, Vera Lúcia Bosa ${ }^{3}$, llaine Schuch³, Marcelo Zubaran Goldani ${ }^{3}$, Flávio Kapczinski ${ }^{5}$, Giovanni Abrahão Salum ${ }^{4}$, Carla Dalmaz ${ }^{1,2}$, Gisele Gus Manfro ${ }^{1,4}$ and Patrícia Pelufo Silveira ${ }^{1}$

\begin{abstract}
Background: Although several studies have reported an association between mental disorders and serum levels of brain-derived neurotrophic factor (BDNF), this association is still poorly understood. The study of factors associated with both BDNF levels and mental disorders, such as n-3 polyunsaturated fatty acids ( $n-3$ PUFAs), may help to elucidate the mechanisms mediating the relationship between the two variables. Therefore, the present study aimed to evaluate whether the intake n-3 PUFAs correlates with serum levels of BDNF.
\end{abstract}

Findings: This study involved 137 adolescents drawn from a community sample, including a group with high levels of anxiety, assessed using the Screen for Children and Anxiety Related Emotional Disorders. Blood samples were collected and serum BDNF levels were measured. n-3 PUFAs were estimated using a food frequency questionnaire for adolescents. Correlations were performed to assess the association between n-3 PUFAs intake and BDNF levels. Effects of potential confounders (total fat consumption, age, gender and anxiety) were examined using linear regression models. There was a direct correlation between n-3 PUFAs consumption and serum BDNF levels, which remained significant even after accounting for potential confounders.

Conclusions: We were able to detect a correlation between n-3 PUFAs intake and peripheral BDNF levels. Our study was limited by its small sample size, and our external validity may be restricted by the oversampling of anxious adolescents. Our findings may help determine the nature of the association between mental disorders and serum levels of BDNF. However, more studies are needed to elucidate the possible mechanisms by which n-3 PUFAs intake affects BDNF levels, and how this may lead to an increased vulnerability to psychiatric disorders.

Keywords: Anxiety, Children, Adolescents, SCARED, BDNF

\section{Background}

Brain-Derived Neurotrophic Factor (BDNF) is a dimeric protein thought to be involved in neuronal survival and synaptic plasticity, and to be an important biomarker for psychiatric conditions such as depression and bipolar disorder [1-3]. It is a member of the growth factor family and acts as a regulator of synaptic plasticity, synaptogenesis, as well as neuronal survival and differentiation [4-6]. Therefore, the understanding of processes associated with both

\footnotetext{
* Correspondence: neurocientista@hotmail.com

'Post Graduate Program in Neuroscience, Institute of Basic Sciences/Health,

Federal University of Rio Grande do Sul (UFRGS), Porto Alegre, RS, Brazil

${ }^{2}$ Laboratory of Stress Neurobiology, Biochemistry Department, Federal

University of Rio Grande do Sul (UFRGS), Porto Alegre, RS, Brazil

Full list of author information is available at the end of the article
}

BDNF levels and mental disorders may ultimately help determine the underlying mechanisms responsible for the association between these two variables.

Studies of human subjects have demonstrated that lower per capita fish/seafood consumption, which can be used as a surrogate measurement of $n-3$ polyunsaturated fatty acids (PUFAs) dietary intake, is associated with a higher prevalence of bipolar spectrum disorders $[7,8]$, major depression $[9,10]$ and postpartum depression $[11,12]$. Experimental studies in rats demonstrate that polyunsaturated fatty acids (PUFAs) could modify brain BDNF levels [13-15] and may play an important role in the function and structure of many membrane proteins [16,17]. Nevertheless, there is still a need to investigate whether the

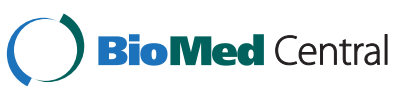

(c) 2014 Ferreira et al.; licensee BioMed Central Ltd. This is an Open Access article distributed under the terms of the Creative Commons Attribution License (http://creativecommons.org/licenses/by/2.0), which permits unrestricted use, distribution, and reproduction in any medium, provided the original work is properly credited. The Creative Commons Public Domain Dedication waiver (http://creativecommons.org/publicdomain/zero/1.0/) applies to the data made available in this article unless otherwise stated. 
relationship between dietary n-3 PUFAs intake and BDNF translates to humans. In light of these above findings, the aim of the present study was to evaluate whether the consumption of $n-3$ PUFAs correlates with serum BDNF levels in humans.

\section{Findings}

The current study involved 137 adolescents drawn from a community sample, including a group with high rates of anxiety ( $64.6 \%$ female; mean age 13.9 years, $\mathrm{SD}=2.42)$, as assessed by the Screen for Children and Anxiety Related Emotional Disorders (SCARED) [18]. A detailed description of the sampling process can be found elsewhere [19]. Briefly, all quartiles of the distribution of SCARED scores were equally represented in the sample (i.e., no to very low anxiety, mild anxiety, moderate anxiety and severe anxiety), although there was an oversampling of participants in the upper quartile (severe anxiety). The SCARED inventory comprises 38 items that can be grouped into subscales according to the different anxiety symptoms investigated, and consists of a screening tool for DMS-IV childhood anxiety disorder. The present study was approved by the Research Ethics Committee of the Hospital de Clínicas de Porto Alegre (GPPG/HCPA, protocol number $08-481)$. Informed consent was provided by all primary caretakers, and all adolescents assented to participate in the study.

Blood samples were collected between 7 and 10 am after a fasting period of 10-12 hours, centrifuged for 5 minutes at $4500 \mathrm{rpm}$, and serum was stored at $-80^{\circ} \mathrm{C}$ in order to measure BDNF levels. All BDNF measurements were performed on the same day by sandwich-ELISA using monoclonal antibodies specific for BDNF (R\&D Systems, Minneapolis, Minnesota), according to the manufacturer's instructions. The intra-assay and inter-assay coefficients of variation were 3.7 and $8.5 \%$, respectively. n-3 PUFAs intake was estimated by a food frequency questionnaire administered to the adolescents (FFQ) [20]. The quantitative analysis of macro and micronutrient intake was performed using the NutriBase ${ }^{\bullet}$ software (Version NB7 Network) [Phoenix, AZ, USD]. Spearman correlations were performed to assess the association between $n-3$ PUFA intake and BDNF levels. The effects of potential confounders (total fat intake, age, gender and symptoms of anxiety) were examined using linear regression models (involving log-transformed BDNF values, logBDNF).

The correlation between $\mathrm{n}-3$ PUFA intake and BDNF levels was statistically significant, $r_{\mathrm{s}}=0.172, p=0.043$ (Figure 1). Multivariate linear regression models showed that even after controlling for the confounders, n-3 PUFA intake was associated with higher levels of $\log B D N F$

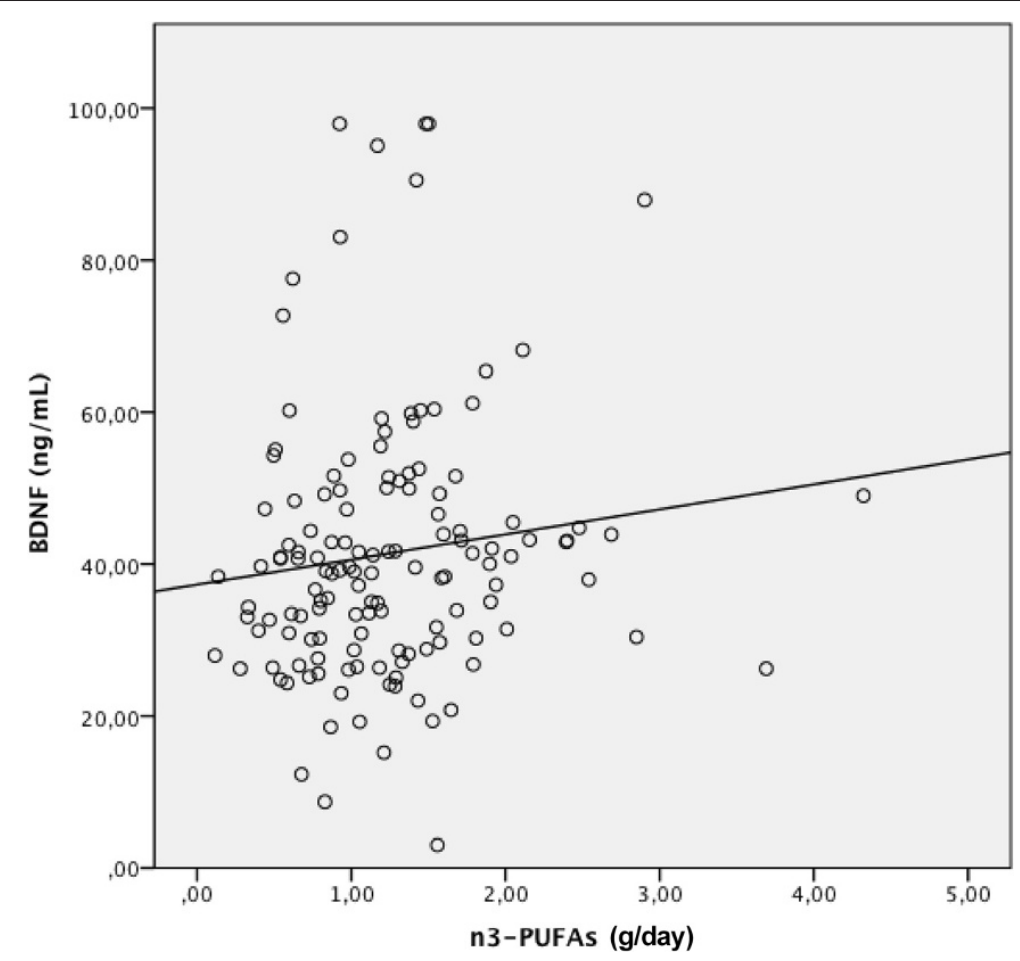

Figure 1 Correlation between n-3 polyunsaturated fatty acids ( $n-3$ PUFAs) intake (g/day) and peripheral levels ( $\mathrm{ng} / \mathrm{mL}$ ) of brain-derived neurotrophic factor (BDNF). The correlation between n-3 PUFAs intake and BDNF levels was statistically significant $\left(r_{s}=0.172, p=0.043\right)$. 
(beta $=.463, \mathrm{t}=2.83, p=0.005)$. No evidence of collinearity was found in the model.

\section{Discussion}

We were able to show that n-3 PUFAs intake is associated with serum BDNF levels in adolescents, corroborating to the suggestion that the relationship between mental disorders and BDNF may be mediated by the intake of nutrients such as n-3 PUFAs. This may influence the cellular and physiological processes involved in psychiatric/mood disorders, such as the fatty acid composition of cellular membranes, the modulation of behavioral systems, neurodevelopment, and oxidative stress in specific brain areas [21-25].

Studies suggest that n-3 PUFA-depleted rodents exhibit changes in emotional status such as elevated aggression, depression and anxiety [26-31]. Moreover, the dietary deprivation of $n-3$ PUFAs in rats may lead to changes in the expression of BDNF in the frontal cortex, in cAMP response element binding protein (CREB) activity and reduce p38 mitogen-activated protein kinase (MAPK) activity [13].

It is noteworthy that the food frequency questionnaire used in the study contained a varied list of 94 foods or drinks [20,32]. Thus, the corresponding food sources to the n-3 PUFAs consumption among students were diverse, including vegetable oils and products/preparations based in oils (e.g. biscuits, mayonnaise and fried foods), according to calculations performed with the values depicted in the American Food Table [33]. Besides fish and oils consumption, red meat is also considered a source of n-3 PUFAs [34], and our region is especially known to have a high consumption of meat. A national survey conducted in both urban and rural areas throughout the country with analysis of individual food consumption in Brazil from 2008-2009 [35], reported that the Southern region of Brazil, including the State of Rio Grande do Sul, where the city Porto Alegre lays, was identified as one of the leading regions in the consumption of red or pork meat. Besides, it was also observed that among 10 to 13 years old population, the n-3 PUFAs displayed a high daily consumption (mean: $1.5 \mathrm{~g}$ ) in this region, compared to other Brazilian regions. Meat intake is traditionally high and typical from our region, which could probably corroborate to the high n-3 PUFAs consumption levels evidenced in this study.

It is important to note that our study is limited by its small sample size, and that the oversampling of anxious adolescents may restrict our external validity. However, in spite of these limitations, we were able to detect a correlation between $\mathrm{n}-3$ PUFAs consumption and serum BDNF levels. The extent to which peripheral BDNF levels are representative of central nervous system BDNF levels remains to be investigated, although positive correlations between serum and cortical BDNF levels have been reported in preclinical studies [36], and cellular and behavioral brain functions have been found to be modulated by peripheral BDNF [37]. Furthermore, serum BDNF levels have been associated with neuronal integrity in healthy subjects [38] and decreased BDNF peripheral levels (i.e. serum or plasma) have been consistently found in patients with mood disorders $[39,40]$. BDNF is implicated in a variety of neural processes and is related to neuronal developmental stages in both animals and humans [39]. Lang, Hellweg, Sseifert, Schubert and Gallinat, 2007 [38] reported that serum BDNF protein concentrarion might reflect some aspects of neuronal plasticity in the living human brain, playing a role as regulators of neuronal survival and differentiation. Similar findings have been reported by Poo, 2001 [6]. Recent studies demonstrate that decreased peripheral BDNF levels are consistently related to disease activity and progression in bipolar disorder [41] as well as to the cognitive impairment seen in patients following their first psychotic episode [42]. More studies are needed to elucidate the possible mechanisms by which n-3 PUFAs consumption affects BDNF levels and influences the vulnerability to psychiatric and mood disorders, especially during certain life stages such as adolescence.

\section{Abbreviations \\ BDNF: Brain-derived neurotrophic factor; DMS IV: Diagnostic and statistical manual of mental disorders IV; ELISA: Enzyme-linked immunosorbent assay; n-3 PUFAs: Omega-3 polyunsaturated fatty acids; PUFAs: Polyunsaturated fatty acids; Rpm: Revolutions per minute; SCARED scale: Screen for children and anxiety related emotional disorders scale.}

\section{Competing interest}

Charles Francisco Ferreira is a CAPES scholarship recipient and declares no potential conflicts of interest. Giovanni Abrahão Salum has a CAPES/FAPERGS post-doctoral scholarship and declares no potential conflicts of interest. Vera Lúcia Bosa and Ilaine Schuch declare no potential conflicts of interest. Flávio Kapczinski, Patrícia Pelufo Silveira, Carla Dalmaz, Gisele Gus Manfro and Marcelo Zubaran Goldani have received research grants from Brazilian government institutions (CNPQ, FAPERGS and FIPE-HCPA).

\section{Authors' contributions}

All authors participated in the study to a significant extent. CFF, JRB, GAS, CD, GGM, PPS worked on data analysis and interpretation, in writing the manuscript and contributed to the intellectual content of the article. VLB, IS, MZG, FK, GAS, GGM and PPS worked on study conception and design, as well as data collection and interpretation, and made intellectual contributions to the article. All authors read and approved the submitted manuscript.

\section{Acknowledgments}

We thank the children and families for their participation. Without them, this research would not have been possible. We also thank the research teams of the Centro Colaborador em Alimentação e Nutrição Escolar (CECANE - UFRGS) and the Fundo Nacional para o Desenvolvimento da Educação do Ministério da Educação (FNDE).

\section{Role of funding source}

CNPq, FIPE-HCPA and FAPERGS provided the funding for the clinicians and interviewers involved in the study, and for the purchase of all necessary materials. CAPES (CFF and GAS), FAPERGS (GAS) and CNPq (FK, PPS, CD, GGM, MZG) provided scholarships to the researchers. No funding agencies participated in the execution of the present study, including data collection, analysis and manuscript preparation. 


\section{Author details}

'Post Graduate Program in Neuroscience, Institute of Basic Sciences/Health, Federal University of Rio Grande do Sul (UFRGS), Porto Alegre, RS, Brazil. ${ }^{2}$ Laboratory of Stress Neurobiology, Biochemistry Department, Federal University of Rio Grande do Sul (UFRGS), Porto Alegre, RS, Brazil. ${ }^{3}$ Center for Child and Adolescent Health Studies (NESCA), Translational Pediatrics Laboratory (LPT), Hospital de Clínicas de Porto Alegre (HCPA), Faculty of Medicine, Federal University of Rio Grande do Sul (UFRGS), Porto Alegre, RS, Brazil. ${ }^{4}$ Anxiety Disorders Outpatient Program for Children and Adolescents, National Institute of Developmental Psychiatry for Children and Adolescents (INPD, CNPq), Graduate Program in Medical Sciences: Psychiatry, Hospital de Clínicas de Porto Alegre (HCPA), Faculty of Medicine, Federal University of Rio Grande do Sul (UFRGS), Porto Alegre, RS, Brazil. ${ }^{5}$ Laboratory of Molecular Psychiatry, Psychiatry Department, Hospital de Clínicas de Porto Alegre (HCPA), Schoool of Medicine, Federal University of Rio Grande do Sul (UFRGS), Porto Alegre, RS, Brazil. ${ }^{6}$ Rua Ramiro Barcelos 2600 Anexo, Departamento de Bioquímica, UFRGS. CEP 90035-000, Porto Alegre, RS, Brazil

Received: 13 December 2013 Accepted: 20 February 2014 Published: 5 March 2014

\section{References}

1. Shimizu E, Hashimoto K, Okamura N, Koike K, Komatsu N, Kumakiri C, Nakazato M, Watanabe H, Shinoda N, Okada S, lyo M: Alterations of serum levels of brain-derived neurotrophic factor (BDNF) in depressed patients with or without antidepressants. Biol Psychiatry 2003, 54:70-75.

2. Kapczinski F, Frey BN, Kauer-Sant'Anna M, Grassi-Oliveira R: Brain-derived neurotrophic factor and neuroplasticity in bipolar disorder. Expert Rev Neurother 2008, 8:1101-1113.

3. Kauer-Sant'Anna M, Kapczinski F, Andreazza AC, Bond DJ, Lam RW, Young LT, Yatham LN: Brain-derived neurotrophic factor and inflammatory markers in patients with early- vs. late-stage bipolar disorder. Int I Neuropsychopharmacol 2009, 12:447-458

4. Park H, Poo MM: Neurotrophin regulation of neural circuit development and function. Nat Rev Neurosci 2013, 14:7-23.

5. Manji HK, Drevets WC, Charney DS: The cellular neurobiology of depression. Nat Med 2001, 7:541-547.

6. Poo MM: Neurotrophins as synaptic modulators. Nat Rev Neurosci 2001, 2:24-32

7. Noaghiul S, Hibbeln JR: Cross-national comparisons of seafood consumption and rates of bipolar disorders. Am J Psychiatry 2003, 160:2222-2227.

8. McNamara RK: Evaluation of docosahexaenoic acid deficiency as a preventable risk factor for recurrent affective disorders: current status, future directions, and dietary recommendations. Prostaglandins Leukot Essent Fatty Acids 2009, 81:223-231.

9. Hibbeln JR: Fish consumption and major depression. Lancet 1998, 351:1213.

10. De Vriese SR, Christophe AB, Maes M: Lowered serum n-3 polyunsaturated fatty acid (PUFA) levels predict the occurrence of postpartum depression: further evidence that lowered n-PUFAs are related to major depression. Life Sci 2003, 73:3181-3187.

11. Shapiro GD, Fraser WD, Séguin JR: Emerging risk factors for postpartum depression: serotonin transporter genotype and omega-3 fatty acid status. Can J Psychiatry 2012, 57:704-712.

12. da Rocha CM, Kac G: High dietary ratio of omega-6 to omega-3 polyunsaturated acids during pregnancy and prevalence of post-partum depression. Matern Child Nutr 2012, 8:36-48

13. Rao JS, Ertley RN, Lee HJ, DeMar JC, Arnold JT, Rapoport SI, Bazinet RP: n-3 polyunsaturated fatty acid deprivation in rats decreases frontal cortex BDNF via a p38 MAPK-dependent mechanism. Mol Psychiatry 2007, 12:36-46.

14. Vetrivel U, Ravichandran SB, Kuppan K, Mohanlal J, Das UN, Narayanasamy A: Agonistic effect of polyunsaturated fatty acids (PUFAs) and its metabolites on brain-derived neurotrophic factor (BDNF) through molecular docking simulation. Lipids Health Dis 2012, 11:109.

15. Ferreira CF, Bernardi JR, Krolow R, Arcego DM, Fries GR, de Aguiar BW, Senter G, Kapczinski FP, Silveira PP, Dalmaz C: Vulnerability to dietary n-3 polyunsaturated fatty acid deficiency after exposure to early stress in rats. Pharmacol Biochem Behav 2013, 107:11-19.
16. Youdim KA, Martin A, Joseph JA: Essential fatty acids and the brain: possible health implications. Int J Dev Neurosci 2000, 18:383-399.

17. Spector AA, Yorek MA: Membrane lipid composition and cellular function. $J$ Lipid Res 1985, 26:1015-1035.

18. Isolan L, Salum GA, Osowski AT, Amaro E, Manfro GG: Psychometric properties of the Screen for Child Anxiety Related Emotional Disorders (SCARED) in Brazilian children and adolescents. J Anxiety Disord 2011, 25:741-748.

19. Salum GA, Isolan LR, Bosa VL, Tocchetto AG, Teche SP, Schuch I, Costa JR, Costa Mde A, Jarros RB, Mansur MA, Knijnik D, Silva EA, Kieling C, Oliveira MH, Medeiros E, Bortoluzzi A, Toazza R, Blaya C, Leistner-Segal S, Salles JF, Silveira PP, Goldani MZ, Heldt E, Manfro GG: The multidimensional evaluation and treatment of anxiety in children and adolescents: rationale, design, methods and preliminary findings. Rev Bras Psiquiatr 2011, 33:181-195.

20. Willett WC: Nutritional Epidemiology. Oxford: Oxford University Press; 1998.

21. Balanzá-Martínez V, Fries GR, Colpo GD, Silveira PP, Portella AK, TabarésSeisdedos R, Kapczinski F: Therapeutic use of omega-3 fatty acids in bipolar disorder. Expert Rev Neurother 2011, 11:1029-1047.

22. Liperoti R, Landi F, Fusco O, Bernabei R, Onder G: Omega-3 polyunsaturated fatty acids and depression: a review of the evidence. Curr Pharm Des 2009, 15:4165-4172.

23. Rombaldi Bernardi J, de Souza ER, Ferreira CF, Pelufo Silveira P: Fetal and neonatal levels of omega-3: effects on neurodevelopment, nutrition, and growth. ScientificWorldJournal 2012, 2012:202473.

24. Tur JA, Bibiloni MM, Sureda A, Pons A: Dietary sources of omega 3 fatty acids: public health risks and benefits. Br J Nutr 2012, 107(Suppl 2):S23-S52.

25. Williams LL, Kiecolt-Glaser JK, Horrocks LA, Hillhouse JT, Glaser R: Quantitative association between altered plasma esterified omega- 6 fatty acid proportions and psychological stress. Prostaglandins Leukot Essent Fatty Acids 1992, 47:165-170.

26. Zimmer L, Hembert S, Durand G, Breton P, Guilloteau D, Besnard JC, Chalon S: Chronic $n-3$ polyunsaturated fatty acid diet-deficiency acts on dopamine metabolism in the rat frontal cortex: a microdialysis study. Neurosci Lett 1998, 240:177-181

27. Fedorova I, Salem N Jr: Omega-3 fatty acids and rodent behavior. Prostaglandins Leukot Essent Fatty Acids 2006, 75:271-289.

28. Zimmer L, Delion-Vancassel S, Durand G, Guilloteau D, Bodard S, Besnard JC, Chalon S: Modification of dopamine neurotransmission in the nucleus accumbens of rats deficient in $n-3$ polyunsaturated fatty acids. $J$ Lipid Res 2000, 41:32-40.

29. Zimmer L, Vancassel S, Cantagrel S, Breton P, Delamanche S, Guilloteau D, Durand G, Chalon S: The dopamine mesocorticolimbic pathway is affected by deficiency in n-3 polyunsaturated fatty acids. Am J Clin Nutr 2002, 75:662-667.

30. Mathieu G, Oualian C, Denis I, Lavialle M, Gisquet-Verrier P, Vancassel S: Dietary n-3 polyunsaturated fatty acid deprivation together with early maternal separation increases anxiety and vulnerability to stress in adult rats. Prostaglandins Leukot Essent Fatty Acids 2011, 85:129-136.

31. Mathieu G, Denis S, Lavialle M, Vancassel S: Synergistic effects of stress and omega-3 fatty acid deprivation on emotional response and brain lipid composition in adult rats. Prostaglandins Leukot Essent Fatty Acids 2008, 78:391-401.

32. Slater B, Philippi ST, Fisberg RM, Latorre MR: Validation of a semiquantitative adolescent food frequency questionnaire applied at a public school in São Paulo, Brazil. Eur J Clin Nutr 2003, 57:629-635.

33. USDA: National Nutrient Database for Standard Reference, Release 25. 2012.

34. Howe PR, Meyer BJ, Record S, Baghurst K: Contribution of red meat to very long chain omega-3 fatty acid (VLCOmega3) intake. Asia Pac J Clin Nutr 2003, 12:527.

35. IBGE: Pesquisa de Orçamentos Familiares 2008-2009, Análise de Consumo Alimentar no Brasil. 2011: Instituto Brasileiro de Geografia e Estatística (BGE); 2011.

36. Karege F, Schwald M, Cisse M: Postnatal developmental profile of brainderived neurotrophic factor in rat brain and platelets. Neurosci Lett 2002, 328:261-264.

37. Schmidt HD, Duman RS: Peripheral BDNF produces antidepressant-like effects in cellular and behavioral models. Neuropsychopharmacology 2010, 35:2378-2391.

38. Lang UE, Hellweg R, Seifert F, Schubert F, Gallinat J: Correlation between serum brain-derived neurotrophic factor level and an in vivo marker of cortical integrity. Biol Psychiatry 2007, 62:530-535. 
39. Frey BN, Andreazza AC, Houenou J, Jamain S, Goldstein BI, Frye MA, Leboyer M, Berk M, Malhi GS, Lopez-Jaramillo C, Taylor VH, Dodd S, Frangou S, Hall GB, Fernandes BS, Kauer-Sant'Anna M, Yatham LN, Kapczinski F, Young LT: Biomarkers in bipolar disorder: a positional paper from the International Society for Bipolar Disorders Biomarkers Task Force. Aust N Z J Psychiatry 2013, 47(4):321-332.

40. Grande I, Kapczinski F, Stertz L, Colpo GD, Kunz M, Cereser KM, Kauer-Sant'Anna M, Frey B, Vieta E, Magalhaes PV: Peripheral brain-derived neurotrophic factor changes along treatment with extended release quetiapine during acute mood episodes: an open-label trial in drug-free patients with bipolar disorder. J Psychiatr Res 2012, 46:1511-1514.

41. Fernandes BS, Gama CS, Ceresér KM, Yatham LN, Fries GR, Colpo G, de Lucena D, Kunz M, Gomes FA, Kapczinski F: Brain-derived neurotrophic factor as a state-marker of mood episodes in bipolar disorders: a systematic review and meta-regression analysis. J Psychiatr Res 2011, 45:995-1004.

42. Ruiz de Azua S, Matute C, Stertz L, Mosquera F, Palomino A, de la Rosa I, Barbeito S, Vega P, Kapczinski F, González-Pinto A: Plasma brain-derived neurotrophic factor levels, learning capacity and cognition in patients with first episode psychosis. BMC Psychiatry 2013, 13:27.

doi:10.1186/1476-511X-13-44

Cite this article as: Ferreira et al:: Correlation between $n-3$ polyunsaturated fatty acids consumption and BDNF peripheral levels in adolescents. Lipids in Health and Disease 2014 13:44.

\section{Submit your next manuscript to BioMed Central and take full advantage of:}

- Convenient online submission

- Thorough peer review

- No space constraints or color figure charges

- Immediate publication on acceptance

- Inclusion in PubMed, CAS, Scopus and Google Scholar

- Research which is freely available for redistribution 